\title{
TECHNOLOGY, GLOBALISATION, AND GOVERNANCE: RESEARCH PERSPECTIVES AND PROSPECTS
}

Tony Cornford

London School of Economics and Political Science, London, UK

Diego D. Navarra

International Institute for Geo-Information Science and Earth Observation (ITC), The Netherlands

Abstract The purpose of this chapter is to introduce global ICT programmes, defined as new and universal modes of organising mediated by technology and enacted through a novel mix of policy instruments, international institutions, business interests, and techno/managerial concepts. Largely unexplored in various fields, including information systems as well as many other social sciences studying innovation and digital technologies, such programmes are interesting, not least because of their projected ability to promote innovation and achieve new mechanisms of governance. The chapter argues that a new theoretical understanding for the study of such programmes is needed in order to explore them as a means of technology transfer and to better understand systems of innovation in the developing world.

Keywords: Globalisation, governance, networks, e-government.

\section{Introduction}

Joseph E. Stiglitz in his book "Globalisation and Its Discontents" [46] points out that the greatest disparity between developed and less developed nations is not anymore only or principally a matter of natural resources, or even of human capital (increasingly mobile as it is), but is the growing divide in access to organisational capacity and the extent to which this impedes the coordination and exploitation of informational resources. This organisational capacity is often directly associated with the ability to embody ICT within networked structures that link government to economic and social development in new ways. As Castells suggests, late capitalist societies exhibit such network-based social and economic structures, both within government and administration and beyond in the economy and wider civil society $[9,10,13]$. These structures are increasingly identified as the significant instrument for the expansion of liberal capitalism through innovation and new forms of decentred concentration, alias new modes of 
organising based on digital networks and assembling complex meshes of activities and territories that cross conventional borders [45].

As a consequence, across the world it is possible to identify a movement, or a strong set of claims, for the introduction of programmes to shift from "government" as a primary responsibility of the unitary state, to "governance" by and through networks of institutions and individuals (and technological entities too, as discussed below), acting in partnership, held together by relations of trust, and transcending many old and established boundaries [6]. The webs of power and knowledge that these initiatives enact are often presented as being fundamental to the dynamics of technological, organisational, and social innovation in both developed and the developing socio-economic contexts. Mobilising technological capacity, the diffusion of networking and communication infrastructure and the stabilisation of the Internet as the new platform for global communications (telephony, data and images, broadcasting), is often understood as central in this process of change. Indeed, ICT is often identified as a primary actor in enabling national and regional economies to develop new social and organisational capacity and exploit new knowledge assets. This, it is proposed, can then lead to a better ability to participate in the wider global economy and serve as a primary means to achieve social and economic development [50].

However, this is not an easy or obvious path to follow, and meets many challenges in both developed and developing regions of the world. The sense of breakdown or crisis of the welfare state seen in many developed countries might be seen as one consequence of the fundamental shift that is implied by such developments in the contract between capital, labour, and the state, while the developing world faces formidable challenges in responding to this new reality. Typical challenges for developing countries include the creation of institutions in support of the new global and electronic markets as well as providing an enabling policy environment that can support social inclusion and offer institutional transparency while building regimes for foreign investment and participation in global trade $[19,47]$.

This can be conceptualised in terms of what Rose and Miller term a new and distinctive "programme of government" [43], understood as a specific contemporary problematisation of the question of the nature of the State and the drivers of its power and legitimacy. What we see emerging is a programme of government that draws heavily on information and communication technology, and which transcends the nation state, offering a distinctive problematisation of the nature of citizenship, statehood, and citizen/state relations - what we term here as global ICT programmes. These represent a programme of government that expresses a fundamental commitment to the proposition that ICT and informational resources can significantly increase organisational coordination and effectiveness in the business of government (Stiglitz's “organisational capacity”) and on a scale that takes us beyond the nation state. Such programmes seek to support transactions taking place among diverse social and economic actors, organisations, and institutions which operate in a global space. Examples of such 
global ICT programmes can be found in the widespread commitment to egovernment as a technology of transformation, in the establishment of global electronic markets for primary resources, in health information systems and biosurveillance, or in the establishment of global projects to address climate change through carbon trading, organic agriculture, and land and water management.

The primary characteristics of global ICT programmes include:

- the establishment of new networked and distributed modes of organising mediated by technology and operating in the area of government, policy making, regulation and infrastructure development - often on a scale that goes beyond any one country;

- the application of a "toolbox" of policy instruments and guidelines to build and operate such systems, often identified with the general goal of promoting better (or good) governance, harnessing the market and the power of education and information;

- the presence of a common set of institutional and technical actors that operate across contexts and domains, building synergies as they mobilize and develop their technical and managerial knowledge resources.

These programmes themselves are fundamentally global. This is not a question of their application area going beyond the state (though it often will), but of the character of the mobilization that enacts and sustains them. In this mobilization we see three important drivers that bring a global dimension: first, the technologies applied are universal and generic (e.g., the Internet, data management, web sites); second, the values and goals they inscribe are universal (e.g., liberal capitalism, good governance, management and planning methodologies $)^{1}$; third, the networks of agencies which carry them out are universal including bilateral and more often multilateral development and financial institutions such as the OECD, World Bank, and UN bodies, but also business schools, international management consultancies, technology companies, and the institutions of the scientific elites.

Of course, in emphasizing the global and universal character of these programmes - the scale of the materials out of which they are conceived and constructed - we do not want to imply that they operate across the world always in the same way. Indeed, quite the opposite. It is in the character of global ICT programmes that they mutate in local environments; operating as what Sassens calls formats of electronic space, which are inflected by the values, cultures, power systems, and institutional orders in which they are embedded, being appropriated and re-made in various ways in various settings [44]. In the end the "globality" of these programmes is not found in any flat uniformity, but in their interconnected diversity.

We should also be clear that there is nothing inherently good about global ICT programmes. They seem to serve a certain ideology of liberal modernity, with

\footnotetext{
${ }^{1}$ In the context of the present paper, liberal capitalism and good governance are not intended to be equivalent, compatible or complementary, but as essential values of reference for the definition of the goals and priorities implicitly or explicitly linked to Global ICT Programmes.
} 
perhaps a strong Anglo-Saxon bias in their technical/rational and managerial character. They can and should be challenged; among other reasons we could suggest for their cultural myopia and insensitivity, their naive utilitarianism, their allegiance to certain power elites, or their fragility in the face of context and diversity. However, this chapter is not such a critique, rather we seek to understand and outline relevant research perspectives and prospects for global ICT programmes.

Global ICT programmes are usually explicitly linked to transformative agendas; they aim to make a big difference and change things. Examples would include e-government projects to "re-invent" government, regional health information systems, or programmes established within the frameworks of international development activity and focused on the notion of "good governance" [15]. Good governance in particular is often identified as an obligatory passage point for access to wider development and aid programmes and thus to participation in the global economy. The term "governance" as used here signifies something specific in terms of the changes that are expected within such programmes. Governance in general refers to a changed condition of recorded rule, a new process of governing, or a new method by which society is governed [42], with society understood as more than encompassed by the state. Thus, the OECD gives governance a global dimension as "the way society collectively solves its problems and meets its needs [...]. In a framework of good governance, government services across administrative levels co-ordinate their activities in order to enhance the global effectiveness of policies and minimize conflicting action" (our emphasis) [37].

Implicit in such programmes is a fundamental change in the relationship between state and citizens; potentially increasing the importance of citizens' and other mediating body's participation and feedback, and their role in policy formulation, implementation, and enforcement. E-government programmes, for example, are often noted for the way in which they describe and project a distinct conceptualisation of the citizen - as customer or consumer - but also as participant.

Programmes of e-governance then project a distinctive conceptualisation of how ICT is implicated in the blurring and re-shaping of the boundaries of the state, the establishment of new local and global institutional regimes, and in offering new modalities of governance. The legitimization and implementation of global ICT programmes is achieved through international and transnational initiatives and produces a variety of new organisations, control structures, formal and informal rules and codes of practice, all of which start to delineate a new (and not always very coherent) global governance architecture. And yet we see no single or coherent theoretical perspective that can be applied to study such phenomena and the structures of governance that emerge out of the diversity, complexity, but strongly totalising character of these programmes.

Such views lead us to ask some new but fundamental questions: how are we to understand such programmes and what is their contribution to the processes and 
dynamics of globalisation? How can we explain their character, using what theoretical perspectives? And, how should we link such programmes to contemporary notions of governance and social and economic innovation? To start to address these questions we argue for the need to develop new theoretical frameworks and new conceptual categories. In the next section we review the literature on technology, globalisation, and governance. The third section explores three well known epistemological approaches in the discipline of Information Systems and assesses their potential for research in this area. The fourth section returns to the questions above juxtaposing them to the research perspectives identified in section three. Conclusions follow.

\section{Technology, globalisation and governance: Global ICT programmes and development}

Technological progress in the field of information handling, data storage and retrieval systems, networking, and communication is typically identified as the prime driver of social and economic change in the last three decades. Manuel Castells for instance, suggests that globalisation can best be understood by looking at the processes of interconnection that create a global information society [9-11, 13]. He stresses that ICT has facilitated the emergence of a "network society" based on the a-spatial nature of flows of finance, information, and knowledge. Other authors parallel the phenomenon of globalisation to a programme of modernity based on the advancement and expansion of global capitalism, market principles, and economic efficiency [5, 22-25, 27, 41]. As Avgerou \& Madon point out, these ambitions are premised on the adoption of organisational processes from business practice, for example Total Quality Management, process re-engineering and business planning, and are sponsored by international organisations and technology suppliers to facilitate the introduction and diffusion of new forms of organisation and governance as, for instance, in e-government programmes [23, 15, 35].

Both in seeking to promote and to regulate the forces released by the process of globalisation, new mechanisms of regional and global governance have been put in place, which stand in an ambiguous relationship with existing mechanisms of national accountability [28]. Exclusive attention to the national level of aggregation becomes less useful in the light of the changes occurring in the organisation of economic activities, which increasingly tends to diminish the capacity of nation states to act freely even within their boundaries. Castells has argued that the world is being transformed from a "space of places" into a "space of flows" [11, 12], making the nature of the dialectical relations between these spaces and the consequences of these relations key issues for understanding the changing contours of state governance, but also for national and regional development.

Karl Polanyi's in his magisterial work The Great Transformation [40] suggests that the greatest difficulty in establishing a new economic order is contained in the 
social structures which will enact it. In the present time of institutional reconstruction, these ideas are still valid in defining the important distinction between "embedded" and "disembedded" economic orders. In the difficulty of achieving domestic stability without triggering conflict at the international level, it is possible to appreciate the differences between local and disembedded forms of governance and the emergence of an architecture (leading in Polanyi's time to the Bretton Woods international agreement and institutions) for the management of economic transactions by means of bilateral but primarily multi-lateral institutions and collaborations, projecting the activities of the nation state into the international realm. This is what led to Polanyi's prediction of the end of "capitalist internationalism". But, although according to Peter Evans [17] his findings have been disproved by the evident international organisation of production in the past 60 years, it is nonetheless possible to appreciate the way in which the introduction of ICT into governance structures contributes to a new great transformation in the balance between market and state authority as it has been defined since the end of World War II.

Ciborra provides a conceptualisation of the aspirations of global ICT programs in such terms, emphasising the strong role of technology as an actor: "characterised by the extension of the links (networks) to individuals and organisations they support. Software guarantees the standardisation of the linkages, for seamless transfer of data and access to powerful databases, which can also track usage and profile users" [4]. Ciborra conceptualises these novel structures as "grid technologies" - technologies that serve to achieve both a decomposition and a re-composition of existing highly institutionalised activities initially found in a collection of heterogeneous and fragmented systems [45]. These grids then come to support a system of decentred concentration, alias the relocation, sharing, and coordinated use of diverse resources (including organisational capacities) almost irrespective of their geographical, cultural, or organisational context. Such a move serves to decompose and distribute through the grid (networks) things that were previously monolithic or local - what Foster calls "host centric services" [21].

To bring together ICT, management ideas, and the networks of organisations and institutions engaging in developmental efforts, and to expose the emerging governance arrangements they imply is not easy. Such global ICT programmes present a difficult, diffuse, and challenging object of analysis and, as we show below, this is an area that does not surrender immediately to the theories in good currency in the discipline of Information Systems. For example, the ways in which the transfer of technology and organisational forms are combined in global ICT programmes will be associated with such diverse areas as agreements related to trade and the introduction of market supporting regulations in the area of telecommunication, labour mobility, intellectual property, and information services, as well as participation in global financial and transport networks, education and training programmes, research and development capacity, and overall strategies for social and economic development. 
A number of influential reports have been written by multilateral donor and international standard setting organisations on the underlying rationale, effects, and potential of ICT, e-government, and information society initiatives to promote development and reform; in effect promoting a global ICT programme. For example, according to the First Annual Report of the Information and Communication Technologies Task Force of the United Nations: "while domestic policies are needed to harness ICT for development effectively, international policies forged in multilateral institutions will increasingly define the range of policy options available to developing countries" [7] [emphasis added]. Similarly, according to Okot-Uma [38] "E-Governance seeks to realize processes and structures for harnessing the potentialities of information and communication technologies [...] for the purpose of enhancing Good Governance" (emphasis in the original).

Most countries, those with ambitions for development, see an imperative in the rapid diffusion and consolidation of ICT, a process that depends on a number of factors including establishing basic infrastructure, but also investment in research and development by the public and private sectors, sustaining centres of academic excellence, building local industrial and organisational capacity, and then intertwining each element to create dynamic and self-sustaining "systems of innovation" [36]. However, the transition to a developing and dynamic economy and a "good governance" society demands epochal passages and implies efforts beyond any narrow trickle-down rhetoric. It seems to demand a re-shaping of government - its re-invention - in a form that aligns with the new demands emerging from local stakeholders who increasingly see themselves and their interests in terms of a participation in a global society. In short, such a route to development is not only difficult to achieve, but costly and risky [5, 24, 40].

\section{Research perspectives}

Since the 1970s a variety of emerging theoretical approaches, such as population ecology, neo-institutional theory, resource dependence theory, and transaction costs economics, have been proposed as ways to view organisations as "open systems" with structures and internal processes that are determined primarily by environmental factors [39]. However, "because technology had always been regarded as an internal attribute of the organisation, they have proved difficult to combine an interest with technology and innovation [and] the open systems perspectives that have come to dominate macro-organisational research" [39], and especially so for the research and study of network forms of organisations.

Here we assess three potential approaches that may allow us to penetrate further and to explore global ICT programmes as complex and encompassing socio-technical arrangements. We have chosen to assess here the contrasting approaches of Actor Network Theory (ANT) drawn from Science and Technology Studies (STS), Transaction Cost Analysis (TCA), and New Public Management 
(NPM). Each provides a potentially important perspective for expanding our understanding of the phenomenon. ANT allows us to study the role of formal and informal actors, human, social, and material, and their struggles for the maintenance and expansion of power and legitimacy. New Public Management, on the other hand, takes an unequivocal perspective of modernisation and reform, drawing on business and managerial models, and views technology as essentially a package or instrument that can enable certain technical/rational programmes of action. Transaction Costs Analysis in contrast takes the transaction as its unit of analysis, and helps to reveal ICTs as agents of optimisation, serving efficiency in organisational structures and institutional arrangements.

To be sure we cannot suggest that these choices represent the only potential theoretical means to explore global ICT programmes, or that they are ontologically compatible. What we do, however, suggest is that in the contrast between them we may be able better to illuminate aspects of global ICT programmes

ANT is one important strand of work that has attempted to transcend the problems identified by Podolny et al. [8, 31]. ANT builds on techniques of sociology, anthropology, and history to allow us to examine technology as an actor located within networks of hybrid interests. The initial development of ANT was concerned with the sociology of science and was pioneered at the Ecole des Mines in Paris [8]. Later work has included a focus on information and communication technology [32]. ANT rejects any distinction between technology and society proposing that both should be studied the same way using same language and metaphors. According to ANT, a technological innovation is developed and adopted through the building of a heterogeneous network of alliances of human and non-human actors, or actants.

ANT does not distinguish between human and non-human in assigning agency, nor does it specify a conventional unit of analysis; the network can be small or large, in the latter case micro-actor networks are "blackboxed" within the larger. Applying ANT's epistemology it is possible to move through these units of analysis as necessary. ANT does not establish a clear framework for the study of networks governance arrangements, fundamentally a distributed view. Thus, ANT has been criticised for stopping at the identification and description of actors and the networks they adhere to, and as being more persuasive as a means to study events at the local level, but not able to encompass the role played by history and context as innovation unfolds, nor to understand what mattered for the various actors at a specific moment in time [29].

An interesting example of the use of ANT for the study of global ICT networks across developing countries can be found in Braa et al. [4]. The authors draw on actor-network theory to analyse the processes of local translations and alignment with surrounding political institutions and actors in the context of technology transfer to build health information systems. They adopt ANT to extend Castell's network analysis [9] to bridge the global and local dimensions of technology transfer in a dialectic of opposition through counter (local) networks to the 
dominant (global) ones for the development of information infrastructure standards for health information systems in South Africa, India, Cuba and Mozambique. Their findings stress the highly political nature of the development of such infrastructures, which are also influenced by the institutional and economic settings of these countries, suggesting that institutionalisation, understood as local appropriation, can reinforce the sustainability of the aspirations of such networks, in this case to achieve national health information systems that can serve development goals.

The second theoretical perspective that may help in the study of global ICT programmes is Transaction Cost Analysis (TCA) which focuses on the translation of technological artefacts and interests into complex institutional settings and the consequences. This theory has been widely used in information systems research to examine governance arrangements and pricing mechanisms, for example for IT contracts and outsourcing, as well as in the study of e-commerce and e-business [2, 16, 34, 48]. TCA analysis of IT contracts allows for the study of the hierarchical elements of a contract in terms of command structures and authority systems, ruled-based incentive systems, standard operating procedures, nonmarket based pricing systems, and informational dispute resolution mechanisms.

Lee [33] for example argues that IT Service level, transfer of IT assets and staff, pricing and payment terms, warranty and liability, dispute resolution mechanisms and termination, intellectual property rights, and information security and confidentiality, are the most important dimensions in an IT sourcing contract. While this approach has been for the most part applied to business systems the characterizations given above by Lee suggest that there is potential to apply a similar conceptual scheme to global ICT programmes; seeing them as essentially a new transactional framework that will have institutional consequences.

Our final potential theoretical point of departure is New Public Management (NPM). Within the context of the public administration and e-government - itself deeply implicated with the re-definition of the boundaries of the nation state [9] analysis is often associated with a large body of literature under the name of New Public Management (NPM) [14, 15, 18, 20, 30]. This literature places emphasis on the creation of more effective governance and organisational arrangements to increase the state's ability to offer services (if not itself provide them), using novel institutional arrangements, increasing the use of market-oriented mechanisms, and introducing the concept of "partnership" between the public and the private sector, not only as a way to share risks and expenses of experimentation, but also to create and exploit an information infrastructure that is better able to provide efficient service delivery as well as innovation in policy. 


\begin{tabular}{|l|l|l|l|}
\hline Key issues & \multicolumn{1}{|c|}{$\begin{array}{c}\text { Actor Network } \\
\text { Theory } \\
\text { (ANT) }\end{array}$} & $\begin{array}{c}\text { Nerspective } \\
\text { Management } \\
\text { (NPM) }\end{array}$ & $\begin{array}{c}\text { Tosts Analysis } \\
\text { (TCA) }\end{array}$ \\
\hline $\begin{array}{l}\text { Territory \& } \\
\text { Context }\end{array}$ & $\begin{array}{l}\text { Situated social actors, } \\
\text { groups with } \\
\text { overlapping and } \\
\text { shifting interests, } \\
\text { participants in } \\
\text { different social } \\
\text { worlds }\end{array}$ & $\begin{array}{l}\text { Organisations as } \\
\text { formal units, formal } \\
\text { organisational } \\
\text { arrangements, } \\
\text { hierarchy of authority }\end{array}$ & $\begin{array}{l}\text { Small groups and } \\
\text { individuals, task } \\
\text { groups and their } \\
\text { interaction, } \\
\text { organisational } \\
\text { resources and } \\
\text { rewards }\end{array}$ \\
\hline $\begin{array}{l}\text { Form of Authority, } \\
\text { Regulation \& Governance }\end{array}$ & $\begin{array}{l}\text { Actor/environment } \\
\text { Translation and } \\
\text { Inscription }\end{array}$ & $\begin{array}{l}\text { Package as milieu, } \\
\text { Instrumental/ } \\
\text { managerial }\end{array}$ & $\begin{array}{l}\text { Allocate resources } \\
\text { to reduce } \\
\text { transaction costs }\end{array}$ \\
\hline Citizenship & $\begin{array}{l}\text { Membership and } \\
\text { negotiated social } \\
\text { meaning }\end{array}$ & Citizen as Customer & $\begin{array}{l}\text { Contractual \& } \\
\text { Transactional }\end{array}$ \\
\hline Ideology & $\begin{array}{l}\text { Fulfilment through } \\
\text { evocation of meaning }\end{array}$ & $\begin{array}{l}\text { Modernisation, } \\
\text { management and } \\
\text { reform }\end{array}$ & Market, Firm \\
\hline Research Interests & $\begin{array}{l}\text { Maintenance and/or } \\
\text { expansion of power }\end{array}$ & $\begin{array}{l}\text { Organisational } \\
\text { performance and } \\
\text { order }\end{array}$ & $\begin{array}{l}\text { Organisational } \\
\text { forms, } \\
\text { governance, } \\
\text { structure }\end{array}$ \\
\hline
\end{tabular}

Table 1 Actor Network Theory, New Public Management and Transaction Costs Analysis of global ICT programmes.

Both New Public Management and Transaction Costs approaches advocate that technology works best through the formation of appropriate incentive structures, and via its assumed capacity to increase users' choice through contestability (for instance within electronic markets, through informational and interactive resources for citizens/customers, or by competitive outsourcing).

It is interesting then that research on processes of ICT development within these theoretical traditions has generally been concerned with the study of how technologies are used to facilitate activities or processes taking place within quite narrowly defined organisational and market boundaries. However, and in contrast to the global programmes considered here, the TCA literature, and to a degree NPM too, is based on the assumption that some constraining contract (and the assumed means to enforce it) can act as the key governance mechanism to ensure a successful partnership for the exploitation of ICT applications, and thereby ignores the situation where such relationships for global ICT programmes are typically embedded: namely not primarily between customers and providers of services, but also between diverse political and social institutions and settings. 
This is part of the reason why an integral component of moving to a macrolevel of analysis is found in efforts to align formal and informal structures and the transactions taking place so as to achieve (if not design) better or more appropriate governance arrangements [49]. This means looking also at the environmental externalities that become relevant as structures are transformed from techno/managerial fantasies into accepted and legitimate routines across the multiple realities that constitute the contexts of use [1].

Table 1 summarises these three theoretical perspectives and contrasts their potential contribution for the study of Global ICT Programmes with respect to their view of territory and context, forms of authority (including regulation and governance), ideology, and their interpretation of what constitutes "citizenship".

\section{Conclusions and prospects}

In this chapter we have attempted to establish global ICT programmes as an object of study and explored some potential theoretical perspectives that might be used in studying them. The choices of theoretical approach we have made have drawn upon relevant strands of recent work in the field of information systems. We find each of the theories considered to have some potential, but each to be limited or partial. Each can help us explore some of the characteristics of these programmes, as networks of artefacts and institutions comprising policy making as well as operational and transactional systems, in alliance with certain dominant technical and managerial concepts. From ANT we may appreciate their hybrid nature and dynamic emergence as interests coalesce and align; from NPM we understand their appeal to managerial rationality and the market; while from TCA we draw the ideas of transactional efficiency matched to organisational forms. In each case we can see that they serve to capture some of the characteristics, but none presents itself as the obvious choice. In brief, theorizing global ICT programmes is work to be done. In this more attention will need to be paid to the organisational and governance challenges they pose, and especially the risks and challenges faced in developing an effective and coherent international governance architecture which can meet the challenges of the 21st Century. However, we do not see, as yet, in the literature strong strands of relevant research that explores the distinct character of global ICT programmes.

This may be because Global ICT programmes offer for analysis a rather different set of issues with respect to technology than is usually studied in the discipline of information systems. In this new order neither technological infrastructures, institutional arrangements, nor cultural specifics can be taken as stable or given, but must be seen as in a process of change and transformation. It is in this way fundamental for global ICT programmes to seek flexibility, both in the ways they change and mutate when implemented in (and across) local environments as well as to facilitate transitions from, to, and among developing and developed countries via the translation of ideas and interests. For example, the transport success story of the Brazilian city of Curitiba, or the micro-credit model 
of the Grameen bank from Bangladesh. This underscores the need for research that can frame these programmes in a way that can reflect the diversity of cultural and political contexts they inhabit, as well as the need to encompass in research itself the diversity of organisational ecologies [3].

We thus emphasise the status of global ICT programmes as transnational movements or mobilizations and as representing a new form of governance. They also project a distinctive conceptualization of how ICT is implicated in shaping (constraining and liberating) peoples' lives through the blurring and re-shaping of the boundaries of the state, the establishment of new local and global institutional regimes, the offering of new arenas (markets) for interaction. In this we see them as representing a key transition in global governance, associated with technological change and the potential of ICT and related knowledge activities to offer new modalities of governance, itself central to processes of globalisation [26]. They represent, we argue, a fundamental challenge to the notions of geographical location, boundary regulation, and the jurisdiction of the nation state. They also project a new world where co-operative outcomes, fluid collectivities, and trust based relationships become essential requirements if states and their citizens/customers are to be able to develop and exploit organisational capacities.

Unfortunately, this dynamic is not being paralleled by a similar evolution in the relationship between the political and technological domains (internally and more importantly transnationally), and thus the governance models that we see emerge from global ICT programmes are often incoherent and unbalanced, and not appropriate to current challenges. For example, according to the First Annual Report of the Information and Communication Technologies Task Force of the United Nations: "while domestic policies are needed to harness ICT for development effectively, international policies forged in multilateral institutions will increasingly define the range of policy options available to developing countries" [7] [emphasis added]. Meanwhile a plethora of international bodies and various other social and economic institutions struggle to delineate their responsibilities, while national governments are de facto more responsive than creative in addressing these challenges.

\section{References}

[1] Andreu, R. \& C. Ciborra (1998). Organisational learning and core capabilities development: the role of IT, in R. Galliers and W. Baets (Eds.), Information Technology and Organisational Transformation, Wiley: Chichester.

[2] Ang, S. (1994) Toward conceptual clarity of outsourcing. Business Process ReEngineering, 54, 113-26.

[3] Avgerou, C. (2002). IT as an institutional actor in developing countries. in IFIP WG 9.4. 2002. Bangalore.

[4] Avgerou, C., Ciborra, C., \& Land, F.F. (2004) The social study of ICT: Innovation, actors and contexts. Oxford: OUP.

[5] Beck, U. \& Ritter, M. (1992). Risk society: Towards a new modernity. London: Sage Publications. 
[6] Bevir, M. \& Rhodes, W.R. (2004). Interpreting British governance. British Journal of Politics and International Relations. 6, 129-164.

[7] Birkmeyer, J.D. \& Dimnick, J.B. (2004). The leapfrog group's patient safety practices, 2003: The potential benefits of universal adoption.

[8] Callon, M. (1986). Some elements of a sociology of translation: Domestication of the scallops and the fishermen of St Brieuc Bay, in J. Law, (Ed), Power, action and belief (196-233), London: Routledge \& Kegan Paul.

[9] Castells, M. (1986) The rise of the network society. Massachussetts: Blackwell Publishers.

[10] Castells, M. (1997) The power of identity. 1997, Cambridge, Mass: Blackwell.

[11] Castells, M. (2000) The rise of the network society. 2nd ed. Information age ; v.1. Oxford: Blackwell. xxix, $594 \mathrm{p}$.

[12] Castells, M. (2000). Informational capitalism and social exclusion. UNRISD.

[13] Castells, M. (2001). The internet galaxy. Oxford: Oxford University Press.

[14] Christensen, T.P.L. (Ed.) (2002). New public management: The transformation of ideas and practice. Ashgate: Aldershot.

[15] Ciborra, C. \& Navarra, D.D (2005). Good governance, development theory and aid policy: Risks and challenges of e-government in Jordan. Journal of Information Technology for International Development, 11(2).

[16] deLooff, L. (1995). Information systems outsourcing decision making: A framework, organizational theories and case studies. Journal of Information Technology, 10(4), 281-297.

[17] Evans, P.B. (2005). Counter-hegemonic globalisation: Transnational social movements in the contemporary global political economy. Handbook of Political Sociology, 655-670.

[18] Ferlie, E., MacLaughling, K., \& Osborne, P. (Ed.) (2001). New Public Management: current trends and future prospects. London: Routledge:

[19] Force, D. (2001). Creating a development dynamic. Digital Opportunity Task Force: New York.

[20] Fortin, Y.H.V.H. (2000). Contracting in the new public management: From economics to law and citizenship. Amsterdam: IOS Press.

[21] Foster, I. et al. (2004). The physiology of the grid: An open grid services architecture for distributes system integration.

[22] Giddens, A. (1984). The constitution of society: Outline of the theory of structuration. Cambridge: Polity Press.

[23] Giddens, A. (1985). The nation-state and violence. A contemporary critique of historical materialism. Vol.2. London: Polity.

[24] Giddens, A. (1990). The consequences of modernity. 1990, Cambridge: Polity in association with Blackwell.

[25] Giddens, A. (1991). Modernity and self identity: self and society in the late modern age. Cambridge: Polity Press in association with Basil Blackwell.

[26] Giddens, A. (2006). Europe in the Global Age, London: Polity.

[27] Hall, S., et al. (1992). Modernity and its futures. Understanding modern societies : an introduction, Oxford: Polity Press in association with the Open University.

[28] Held, D. \& McGrew, A. (2002). Governing globalization: power, authority and global governance. Cambridge: Polity Press.

[29] Howcroft, D., Mitev, N., \& Wilson, M. (2004). What we may learn from the social shaping of technology approach, in Social Theory and Philosophy for Information Systems, J. Mingers and L. Willcocks, (Eds), Wiley: Chichester.

[30] Larbi, G.A. (1999). The new public management approach and crisis states. United Nations Research Institute for Social Development: Geneva. 
[31] Latour, B. (1987). Science in action: How to follow scientists and engineers through society. Milton Keynes: Open University Press.

[32] Latour, B. (1999). Pandora's hope: Essays in the reality of science studies. Cambridge, Mass: Harvard.

[33] Lee, M. (1996). IT outsourcing contracts: Practical issues for management. Industrial Management and Data Systems, 1996. 96(1), 15.

[34] Malone, T. \& Yates, J. (1987). Electronic markets and electronic hierarchies Communications of the ACM, 30(6), 484-497.

[35] Navarra, D.D. \& Cornford, T. (2005) ICT, innovation and public management: Governance, models \& alternatives for e-Government Infrastructures. European Conference of Information Systems.

[36]. Nelson, R.R. (1993). National innovation systems: a comparative analysis. New York: Oxford University Press.

[37] OECD (2001). Local partnerships for better governance. 2001, Organisation for Economic Cooperation and Development.

[38] Okot-Uma, R. (2001). Electronic governance: Reinventing good governance. World Bank: Washington.

[39] Podolny, J.M., Stuart, T, \& Hannan, M.T. (1996). Networks, knowledge, and niches: Competition in the worldwide semiconductor industry, 1984-1991. American Journal of Sociology, 102(3), 659-89.

[40] Polanyi, K. (2001) The great transformation: the political and economic origins of our time. 2nd Beacon Paperback ed., Boston, MA: Beacon Press.

[41] Poster, M. (1984) Foucault, Marxism and history: mode of production versus mode of information, Cambridge: Polity.

[42] Rhodes, R. (2000). Governance and public administration, in J. Pierre (Ed.), Debating governance: Authority, steering and democracy (pp. 54-90), Oxford: OUP: Oxford..

[43] Rose, N. \& Miller, P. (1992). Political power beyond the state: Problematics of government. British Journal of Sociology. 43(2).

[44] Sassen, S. (2002), Towards a sociology of information technology. Current Sociology, 50(3), 365-388.

[45] Sassen, S. (2006). Territory, authority, rights: From medieval to global assemblages. Woodstock: Princeton University Press.

[46] Stiglitz, J.E. (2002). Globalization and its discontents. London: Allen Lane.

[47] UNDP (2003) Information and communication technologies for development in Human Development Reports. New York: United Nations Development Programme.

[48] Willcocks, L., G. Fitzgerald, et. al. (1996) To outsource IT or not?: Recent research on economics and evaluation practice. European Journal of Information Systems, 5(3), 143-160.

[49] Williamson, O.E. (2000). The new institutional economics: Taking stock, looking ahead. Journal of Economic Literature, 2000. 38(3), 595-613.

[50] WSIS (2004). Financing ICT for development: A review of trends and analysis of gaps and promising practices. ITU: Geneva. 